\title{
Computer Simulation and Investigations of the Roof Mount Photovoltaic System
}

\author{
https://doi.org/10.3991/ijoe.v15i12.10869 \\ Fatima Sapundzhi \\ South-West University "Neofit Rilski", Blagoevgrad, Bulgaria \\ sapundzhi@swu.bg
}

\begin{abstract}
The interest in the renewable energy sources is increasing due to the depletion of the conventional energy sources and the environmental pollution. In this paper we present a computer simulation and investigations of the roof mounted photovoltaic system. The results of the generated power of the $5 \mathrm{~kW}$ built-in photovoltaic system by months over a period of 5 years are presented. Depending on the meteorological conditions, the investigated photovoltaic system generates year-round energy necessary for the needs of the household.
\end{abstract}

Keywords-Computational modeling; computer simulation inverters; photovoltaic systems

\section{Introduction}

Nowadays, the need for electricity is growing at an unprecedented rate. In the report of the World Energy Outlook 2018 (International Energy Agency's flagship publication) were presented global energy trends. According this report the governments will have a critical influence in the direction of the future energy system. Under current and planned policies, modeled in the New Policies Scenario, energy demand is set to grow by more than $25 \%$ to $2040[1,2]$.

Current energy consumption in the world is highly predominated with fossil fuelbased sources such as oil and gas, and their limited reserves and hazardous environmental effects are unequivocal $[3,4]$. Intensive efforts and major transformations are underway for the global energy sector worldwide to narrow the gap between conventional energy (CER) sources and renewable energy sources (RES) $[5,6]$.

The main advantages of RES are: inexhaustible sources of energy (sun, wind, rivers, organic matter, etc.) and contribute to reducing the dependence on CER (oil, natural gas, coal); constitute (together with energy conservation) the most ecologically sound solution for the effective reduction of carbon dioxide emissions and the combating of the greenhouse effect; domestic sources of energy and contribute to strengthening the energy independence and security of supply at the national level and etc. $[7,8,9]$. The sun is the largest fully RES. Therefore, photovoltaic technologies have the greatest future among all RES. Solar photovoltaic (PV) systems are the fast- 
est growing energy systems and they represent a technology that plays a crucial role in global electricity generation $[10,11,12]$.

The purpose of the present study is to design the basic elements of a photovoltaic installation, to simulate its operational characteristics and to build and investigate the operation of network-connected photovoltaic (PV) system under real operating conditions. The investigated PV system with a power of $5 \mathrm{~kW}$ is located on the roof of an existing residential building in the village of Cherniche, Blagoevgrad, Bulgaria.

\section{Computer Simulation of the Designed PV System}

\subsection{Selection of photovoltaic panels, inverter and design software}

The Q-Cells SE Q, BASE-G2 235 Rev03 $235 \mathrm{~W}$ panels are used to build the PV system. They have higher performance than other modules thanks to the positive sorting technology (Figure 1) [13-18].

Their design allows for higher power output even under low light conditions and better performance due to optimized cellular distances. The model has a high standard of safety that includes a watertight coupling box between the modules, as well as an extremely stable frame, bend resistant, strong wind and snow.

The connection box and connectors have an IP rating class 68. The maximum back-up load capacity is $20 \mathrm{~A}$. It provides reliable protection to prevent power losses from unwanted current leakage, hot-spot protection, and prevents short-circuit between module cells and fire occurrence. the panel is made of $3.2 \mathrm{~mm}$ armored glass, which withstand heavy snow and strong wind. It weighs only $20 \mathrm{~kg}$, which greatly facilitates installation work. The solar panel achieves good efficiency even at low solar radiation.

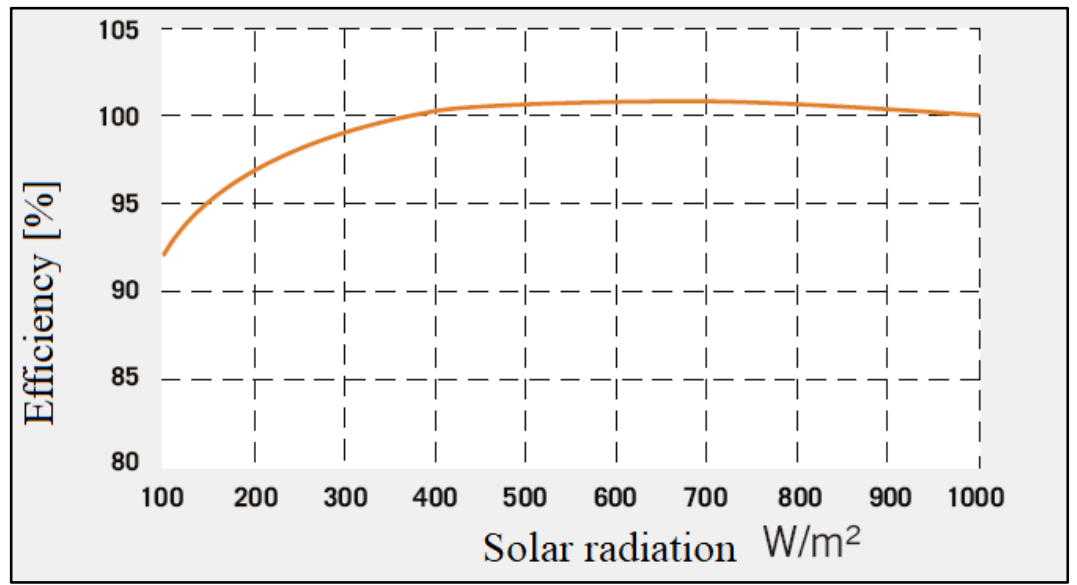

Fig. 1. Efficiency solar modules to solar radiation 
The inverter used to realize the PV system is the Sunny Boy 5000TL (Figure 2). The three-phase inverter offers extremely high efficiency, up to $97 \%$. It has a maximum input voltage of 750 volts, which expands the possibilities of installing a larger number of solar panels: max photovoltaic power $5250 \mathrm{~W}$, max output power 240 $5000 \mathrm{~W}$; frequency $-60 \mathrm{~Hz}$ and max current $-15 \mathrm{~A}$ [15].

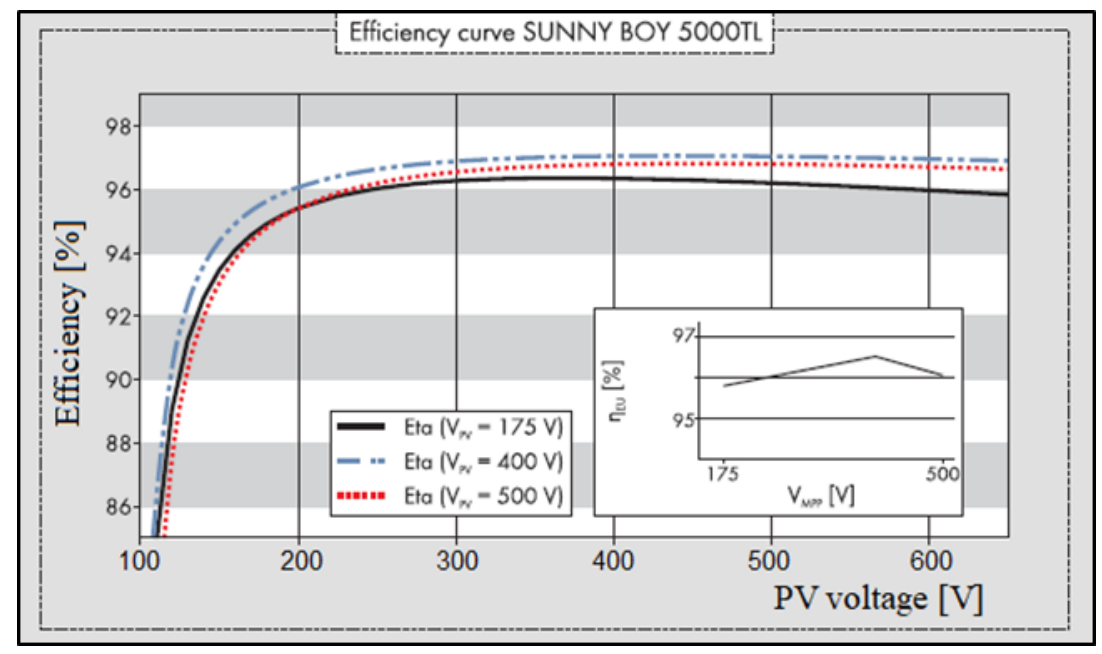

Fig. 2. Efficiency of the inverter performance against PV voltage.

An important advantage of the SB 5000TL inverter is the possibility of emergency power supply. In case of an accident in the power grid, the inverter redirects the generated energy from the photovoltaic system to service the home where it is installed [15-19].

The inverter has a shadow monitoring system called OptiTrac Global Peak. The system is based on an algorithm that monitors shading and adapts quickly to changes in solar radiation that mitigates shadow effects and leads to higher power. Through this system, we can reduce the impact of specific shaded areas on the performance of the photovoltaic system.

The SB5000TL enables real-time tracking of all recorded information from the installation of the inverter to the current moment. It has all the latest technologies for Internet connectivity.

The inverter collects information and records it on a cloud server of the manufacturer, which we can monitor and analyse at any time. The inverter collects information and records it on a cloud server of the manufacturer, which we can monitor and analyse at any time.

The system allows monitoring the status and readings of the inverter via the Internet from different devices such as laptops, tablets, phones. 


\subsection{Computer simulations}

In the current work on the PV simulations, PV Sol software is used. The Blagoevgrad area was chosen for the computer design of the presented photovoltaic system. The investigated PV system is located in the village of Cherniche, Blagoevgrad (Figure 3).

The physical objects surrounding the PV system such as buildings, trees, and other parts can obstruct the light that is able to reach the PV array. One of the aims of the PV design is the minimization of shading, but some shading may be unavoidable, especially in residential rooftop systems.

The first stage of PV system design includes selecting and calculating the target power of the PV system; correct selection of solar panels and solar inverter; good planning of the overall investment; green energy prices survey for the specific region and preparation of all necessary legal documents and permits [15], [16].

The second stage involves computer simulations of the photovoltaic system that maximally reflect the specific features of the terrain and the roof structure in the computer model.

The results of the computer simulation of the PV system are presented in Figure 3. It shows that the maximum power that can generate the photovoltaic panels is 4.70 $\mathrm{kW}[15]$.

The program shows the operating range of the maximum power tracking system from $125 \mathrm{~V}$ to $440 \mathrm{~V}$. It calculates the total power of the photovoltaic system $-4.6 \mathrm{~kW}$ [16].

\begin{tabular}{|c|c|c|c|c|}
\hline \multicolumn{4}{|l|}{ System Check } & $\overline{23}$ \\
\hline Output Check & & \multicolumn{2}{|l|}{ Currents Check } & \\
\hline PV Output per Inverter & $4,70 \mathrm{~kW}$ & Current through Cabling under STC: & $8,01 \mathrm{~A}$ & \\
\hline Inverter AC Power Rating: & $4,60 \mathrm{~kW}$ & $\begin{array}{l}\text { Max. Capacity of Insulated Copper } \\
\text { Wiring, Group C: }\end{array}$ & $45,0 \mathrm{~A}$ & \\
\hline $\begin{array}{l}\text { Sizing Factor: } \\
\text { (PV Output (STC) }\end{array}$ & \multirow[t]{2}{*}{$102 \%$} & Rel. Cabling Losses under STC: & $0,159 \%$ & \\
\hline AC Power Rating) & & $\begin{array}{l}\text { Max. Current through Inverter at } 25^{\circ} \mathrm{C} \text { and } \\
928 \mathrm{~W} / \mathrm{m} \text { ?: }\end{array}$ & $14,9 \mathrm{~A}$ & \\
\hline Permissible Sizing Factor: & $74 \%-104 \%$ & Max. Inverter Input Current: & $15,0 \mathrm{~A}$ & \\
\hline \multicolumn{2}{|l|}{ MPP Voltage Check } & \multicolumn{2}{|l|}{ Upper Voltage Threshold Check } & \\
\hline Inverter MPP Tradking Range: & $125-440 \mathrm{~V}$ & Inverter Max. System Voltage: & $550 \mathrm{~V}$ & \\
\hline \multirow[t]{2}{*}{$\begin{array}{l}\text { PV Array MPP Voltage at } 47^{\circ} \mathrm{C}+300 \mathrm{~W} / \mathrm{m} ? \text { or } \\
-9^{\circ} \mathrm{C}+928 \mathrm{~W} / \mathrm{m}^{2:}\end{array}$} & \multirow{2}{*}{$265 \cdot 335 \mathrm{~V}$} & Module Max. System Voltage: & $1000 \mathrm{~V}$ & \\
\hline & & $\begin{array}{l}\text { PV Array Open Circuit Voltage at } \\
-9{ }^{\circ} \mathrm{C} \text { and } 928 \mathrm{~W} / \mathrm{m} ? \text { : }\end{array}$ & $410 \mathrm{~V}$ & \\
\hline \multicolumn{4}{|l|}{ Unbalanced Load Check } & \\
\hline Current Unbalanced Load: & $4,6 \mathrm{kVA}$ & $\begin{array}{l}\text { Maximum Permissible Unbalanced } \\
\text { Load: }\end{array}$ & $4,6 \mathrm{kVA}$ & \\
\hline \multicolumn{5}{|c|}{$\begin{array}{l}\text { No discrepancies found! } \\
\text { Please observe any design recommendations made by the manufacturer }\end{array}$} \\
\hline \multirow[t]{2}{*}{ Total System } & & & & $\triangle D$ \\
\hline & & ntinue & Help & \\
\hline
\end{tabular}

Fig. 3. Computer simulation of the PV system 


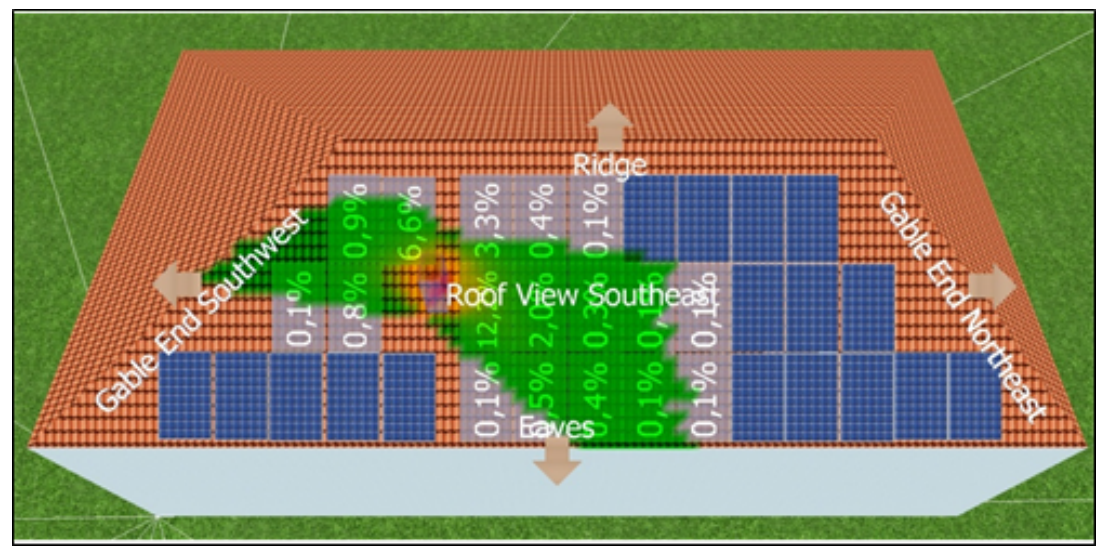

Fig. 4. Simulation showing percentage shading of solar panels

In the photovoltaic installation, 20 solar panels are installed. At the request of the Employer they have power $235 \mathrm{Wp}$. Computer simulation of the PV system showing percentage shading of solar panels is shown in Figure 4. A block diagram of the built PV system is presented in Figure 5.

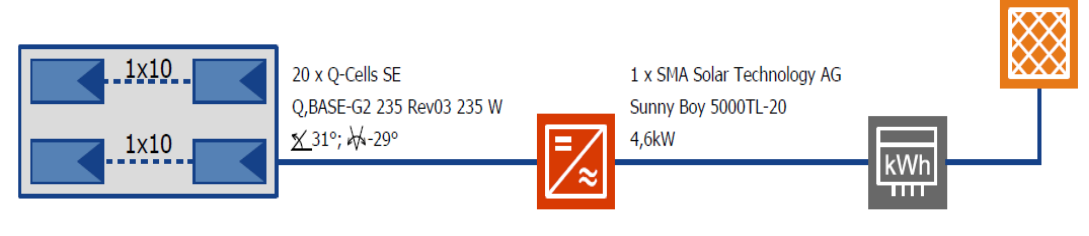

Fig. 5. Block diagram of the PV system

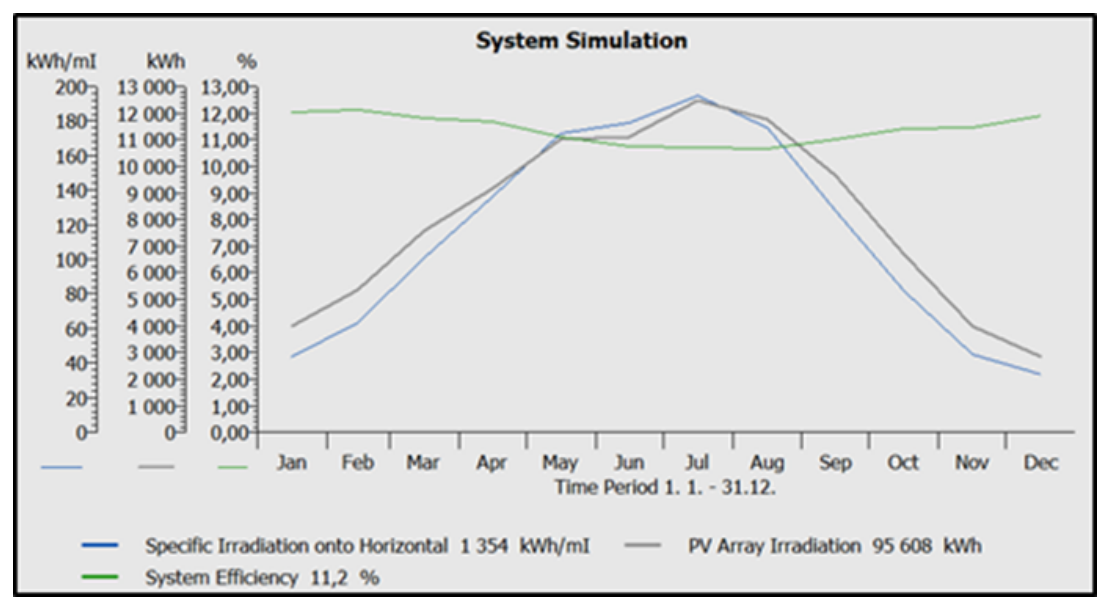

Fig. 6. Amount of energy generated by the PV system in 2018. 
The results of the generated power of the $5 \mathrm{~kW}$ built-in photovoltaic system by months over a period of 5 years are presented in Table 1.

The amounts of energy generated by the photovoltaic system and the percentage distribution of energy for 2018 are presented in Figure 7 and Figure 8.

Table 1. Generated power from the pv system for a period of 5 years

\begin{tabular}{|l|c|c|c|c|c|}
\hline \multicolumn{1}{|c|}{ Months } & $\mathbf{2 0 1 4}$ & $\mathbf{2 0 1 5}$ & $\mathbf{2 0 1 6}$ & $\mathbf{2 0 1 7}$ & $\mathbf{2 0 1 8}$ \\
\hline January & 177,22 & 351,14 & 222,82 & 199,13 & 283,18 \\
\hline February & 490,14 & 482,22 & 373,67 & 348,38 & 234,37 \\
\hline March & 666,29 & 464,71 & 497,22 & 511,65 & 402,32 \\
\hline April & 609,96 & 788,78 & 630,06 & 617,71 & 232,07 \\
\hline May & 773,29 & 859,81 & 654,50 & 652,43 & 720,00 \\
\hline June & 848,83 & 864,58 & 728,41 & 703,02 & 634,60 \\
\hline July & 898,51 & 969,64 & 779,47 & 741,12 & 778,75 \\
\hline August & 873,63 & 845,29 & 729,98 & 711,13 & 751,75 \\
\hline September & 587,67 & 525,04 & 563,51 & 545,04 & 700,90 \\
\hline October & 432,02 & 417,73 & 394,18 & 529,75 & 582,03 \\
\hline November & 255,55 & 165,03 & 273,23 & 241,83 & 308,54 \\
\hline December & 190,98 & 0,00 & 323,47 & 225,71 & 220,77 \\
\hline Total & 6804,07 & 6733,97 & 6170,51 & 6026,89 & 6285,77 \\
\hline
\end{tabular}

Percentage distribution of energy produced by the PV system for 2018 year is presented in Figure 7.

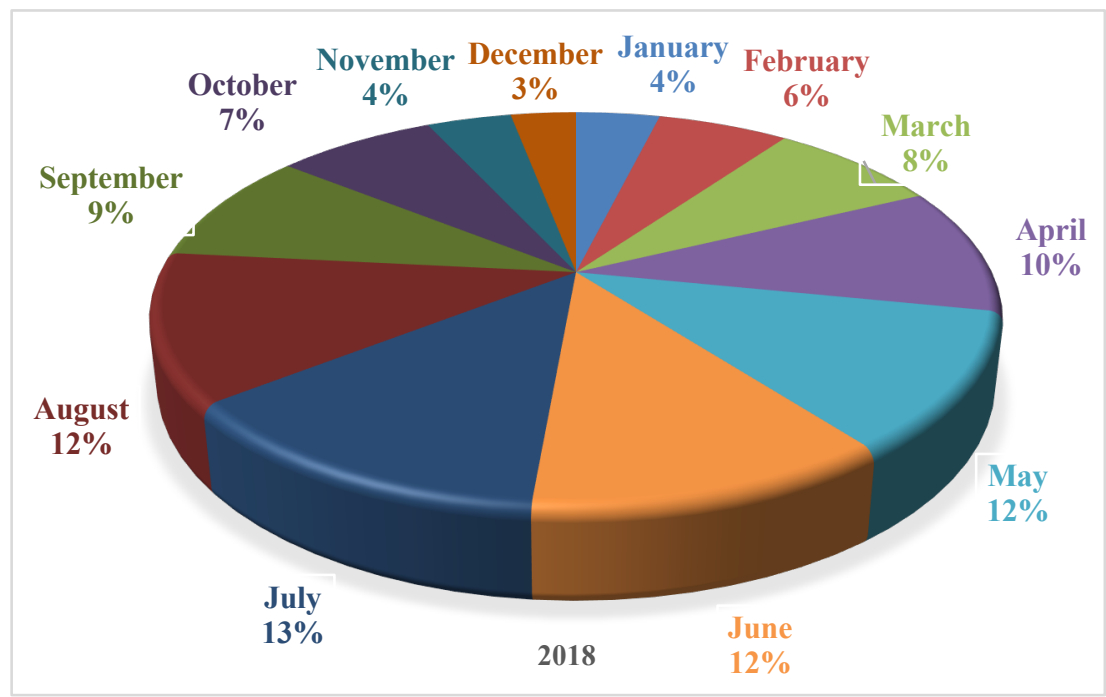

Fig. 7. Percentage distribution of energy produced by the PV system for 2018.

From these results, it can be seen that in May, June, July and August, the highest power generated by the PV system was generated (Figure 7). This is expected due to the power of solar power during this time of the year. 
For the real-time monitoring of the PV system, the Sunny Portal monitoring platform was used. Through this software, the measured values are visualized and analyzed, a comparison of the extracted power over the years, which makes it possible to detect deviations in the operation of the photovoltaic system. The produced energy by the investigated PV system for 2013-2018 years is presented in Figure 8.

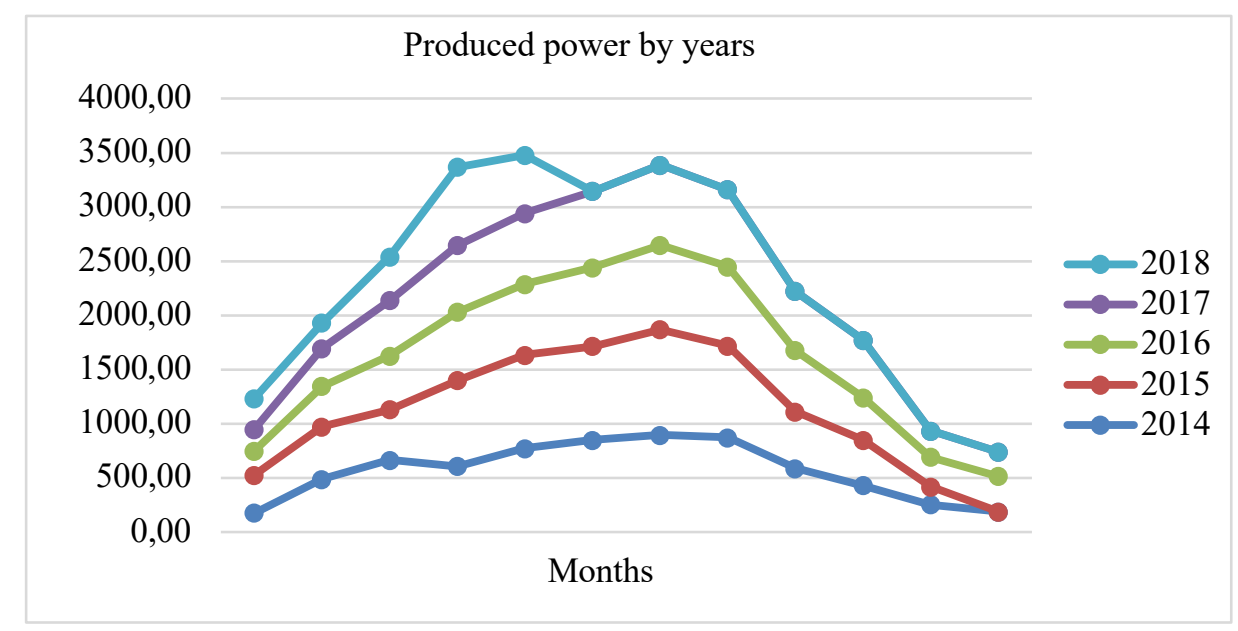

Fig. 8. Produced power by the PV system for five years.

PV-system for a household to supply electricity. According to Köhler et al. the green roofs and PV system can be used together and there is no clash between them [20]. These systems could bring positive effects to building energy conservation and improving of the urban environment [21-25].

\section{Conclusion}

A simulation study was carried out to determine the technical performance of $5 \mathrm{~kW}$ grid-connected rooftop solar. The major findings of the present study are as follows:

- The annual energy yield determined for the system is a good indicator that gridconnected system installations in this region of Bulgaria are technically viable energy solution.

- The annual energy requirement from the electrical grid is reduced by using the proposed PV system.

- The grid-connected rooftop PV system in Cherniche, Bulgaria is technically viable, and the wider implementation of these systems will have substantial benefits in energy savings and $\mathrm{CO}_{2}$ emission reduction.

Depending on meteorological conditions it can be concluded that year-round system generates power necessary for the needs of a household. The analysis of PV in- 
dustry developments in recent years shows an approximate growth of around $40 \%$ per year.

In this work are presented results from the simulation and experimental research of photovoltaic system. The development of technology for the production of photovoltaic panels and rapidly changing climate tends to change, we can conclude that a photovoltaic system will have a better performance in operation than in the simulation. These technologies have enormous potential in countries with high solar resource.

\section{Acknowledgement}

This paper is partially supported by the National Scientific Program "Information and Communication Technologies for a Single Digital Market in Science, Education and Security (ICTinSES)", financed by the Ministry of Education and Science.

We also gratefully acknowledge the support by the company Chikalov EOOD with manager Aleksandar Georgiev Chikalov.

\section{$5 \quad$ References}

[1] https://www.iea.org/weo2018/

[2] https://unstats.un.org/unsd/energy/pocket/2018/2018pb-web.pdf

[3] Cuce E., Riffat S. (2016). A comprehensive assessment of sectoral energy consumption in the UK: past, present and future. International Journal of Low-Carbon Technologies. 11 (3), 424-430, 2016. https://doi.org/10.1093/ijlct/ctv013

[4] Milea P., Zafiu A., Drăgulinescu M., Oltu O. (2010). "MPP tracking method for pv systems, based on a three points prediction algorithm", U.P.B. Sci. Bull. Series C. 72 (4), 149160.

[5] http://www.terna-energy.com/company/The-Sector/ Advantages-Of-RES.

[6] Stoyanov I. (2008). Determination of the electrical energy, obtained from direct transformation of solar energy from a PV generator. Proceedings of twelfth international conference on electrical machines, drives and power systems, ELMA2008, 16 - 18 October, Sofia, Bulgaria, 336-340.

[7] Petkov M. (2004). Calculation of the shading in the PV-generators design. VII International symposium young people and multidisciplinary research, Reşiţa, Romania, 22-23, September 2004.

[8] Zarkov Z., Stoyanov L., Milenov V., Voynova H., Lazarov V. (2016). Modeling of PV generators from different technologies - Case study. Proceedings - 2016 IEEE International Power Electronics and Motion Control Conference, 419-424, 25-28 September 2016. https://doi.org/10.1109/epepemc.2016.7752034

[9] Mohan N., Undeland T., Robbins W. (2003). Power Electronics-Converters Applications and Design, John Wiley \& Sons, 2003.

[10] Rashid M. (2007). Power Electronics handbook: devices circuits and applications. Academic Press.

[11] Cherneva G. (2010). Solution of energy crisis in Bulgaria - challenges and prospects. Proceedings of the XV International Scientific Conference Crises Situations Solution in Specific Environment, ŽU, Žilina, 2-3 June 2010, 261-265. 
[12] Nedyalkov I., Arnaudov D., Hinov N., Kanchev H. (2017). Modelling of an off-grid photovoltaic power supplying system for telecommunication equipment. 15th International Conference on Electrical, Machines, Drives and Power Systems (ELMA), 1-3 June 2017, Technical University of Sofia, Bulgaria. https://doi.org/10.1109/elma.2017.7955402

[13] Deambi S. (2016). Photovoltaic System Design: Procedures, Tools and Applications, CRC Press.

[14] http://www.sunsys.info

[15] http://www.sunnyportal.com

[16] http://solaritybg.com

[17] http://files.sma.de/dl/15330/SB5000TL-21-DEN1551-V20web.pdf

[18] https://multiwatt.de/wp-content/uploads/2012/07/Q-Cells QPRO-G2 Datenblatt DE.pdf

[19] http://files.sma.de/dl/15330/SB5000TL-21-DEN1551-V20web.pdf

[20] Köehler M., Wiartalla W., Feige R. (2007). Interaction between PV-systems and extensive green roofs, 1-16.

[21] Dondariya C., Porwal D., Awasthi A., Shukla A., Sudhakar K., Manohar M., Bhimte A. (2018). Performance simulation of grid connected rooftop solar PV system for small households: A case study of Ujjain, India. Energy Reports. 4, 546-553. https://doi.org/10. 1016/j.egyr.2018.08.002

[22] Kralev V. (2018). Different applications of the genetic mutation operator for symetric travelling salesman problem. International Journal on Advanced Science, Engineering and Information Technology. 8(3), 762-770. https://doi.org/10.18517/ijaseit.8.3.4867

[23] Zhang L., Chen X., Wei K., Zhang W., Feng Y. (2019). Energy Consumption Balanced Topology Variable Routing Algorithm for WWSN in Disaster Rescue Scenarios. International Journal of Online and Biomedical Engineering. 15 (7), 52-65. https://doi.org/10. 3991/ijoe.v15i07.10043

[24] Zheng W., Yang Z., Feng L., Fu P., Shi J. (2019). APP Design of Energy Monitoring in Smart Campus Based on Android System. International Journal of Online and Biomedical Engineering. 15 (7), 18-27. https://doi.org/10.3991/ijoe.v15i05.8225

[25] Nedyalkov, I., Stefanov, A., Georgiev, G. (2018). Modelling and Studying of Cloud Infrastructures. International Conference on High Technology for Sustainable Development, HiTech 2018 - Proceedings, 155-158. https://doi.org/10.1109/hitech.2018.8566664

\section{Author}

Fatima Sapundzhi is Chief Assistant in Department of Communication and Computer Engineering and Technologies, Faculty of Engendering, member of University Center for Advanced, Bioinformatics Research, South-West University "Neofit Rilski", 66 Ivan Mihaylov Str., Blagoevgrad, Bulgaria. PhD on Informatics. Scientific Interest: programming, computer modelling, electrical engineering, biotechnology, bioinformatics.

Article submitted 2019-05-16. Resubmitted 2019-07-10. Final acceptance 2019-07-26. Final version published as submitted by the authors. 